\title{
PERAMALAN JUMLAH PENUMPANG KERETA API DI INDONESIA DENGAN RESILIENT BACK-PROPAGATION (RPROP) NEURAL NETWORK
}

\author{
Mertha Endah Ervina ${ }^{1}$, Rini Silvi ${ }^{2}$, Intaniah Ratna Nur Wisisono ${ }^{3}$ \\ Prodi Magister Statistika Terapan, Universitas Padjajaran ${ }^{1,2,3}$ \\ merthiez@gmail.com ${ }^{1}$, rinisilvi@ $@$ stis.ac.id ${ }^{2}$,rnwintaniah@gmail.com ${ }^{3}$
}

DOI:https://doi.org/10.15642/mantik.2018.4.2.90-99

\begin{abstract}
Abstrak
Penjadwalan kereta api mempengaruhi tingkat kepuasan konsumen dan tingkat keuntungan dari penyelenggara jasa layanan kereta api. Metode prediksi Back-propagation Neural Network (BPNN) terbilang lambat konvergensinya, maka dari itu, penelitian ini menggunakan Resilient Back-propagation (Rprop) karena memiliki teknik konvergensi yang cepat dan tingkat akurasi yang tinggi. Model yang dihasilkan adalah model untuk Jabodetabek, Jawa (non-Jabodetabek), Sumatera, dan Indonesia. Dari hasil analisis data yang dilakukan, dapat disimpulkan bahwa performa model neural network dengan Resilient Backpropagation (Rprop) yang dibentuk dari data training memberikan tingkat akurasi prediksi yang sangat baik/akurat dengan nilai mean absolute percentage error (MAPE) kurang dari 10\% untuk masing-masing model. Kemudian dilakukan peramalan untuk 12 bulan kedepan dan hasilnya dibandingkan dengan data testing, Rprop memberikan tingkat akurasi peramalan yang sangat tinggi dengan nilai MAPE dibawah $10 \%$. Secara lengkap, nilai MAPE untuk masing-masing peramalan jumlah penumpang KA adalah $7.50 \%$ untuk Jabodetabek, 5.89\% untuk Jawa (non-Jabodetabek), 5.36\% untuk Sumatera, dan 4.80\% untuk Indonesia. Artinya, empat arsitektur neural network dengan Rprop dapat digunakan untuk kasus ini dengan hasil peramalan yang sangat akurat.
\end{abstract}

Kata kunci: Resilient Back-propagation (Rprop), Peramalan, Penumpang Kereta Api, nnfor

\begin{abstract}
Train scheduling affects the level of customer satisfaction and profitability of the train service provider. The prediction method of Back-propagation Neural Network (BPNN) has relatively slow convergence. Therefore, this study uses Resilient Back-propagation (Rprop) because it has a more fast convergence and high accuracy. The model produced is a model for Jabodetabek, Java (non-Jabodetabek), Sumatra, and Indonesia. From the results of data analysis conducted, it can be concluded that the performance of neural network model with Resilient Back-propagation (Rprop) formed from training data gives very accurate prediction accuracy level with mean absolute percentage error (MAPE) less than $10 \%$ for each model. Then forecasting for the next 12 months conducted and the results compared with the data testing, Rprop provides a very high forecasting accuracy with MAPE value below 10\%. The MAPE value for each forecasting the number of rail passengers is $7.50 \%$ for Jabodetabek, $5.89 \%$ for Java (non-Jabodetabek), 5.36\% for Sumatra and 4.80\% for Indonesia. That is, four neural network architectures with Rprop can be used for this case with very accurate forecasting results.
\end{abstract}

Keywords: Resilient Back-propagation (Rprop), Forecasting, Rail Passengers, nnfor 


\section{Pendahuluan}

Kereta api merupakan transportasi umum yang banyak digunakan oleh masyarakat baik dalam menunjang kegiatan sehari-hari terkait pekerjaan dan aktivitas harian lainnya yang bersifat rutin maupun sebagai solusi transportasi jarak jauh yang bersifat insidental. Kereta api sebagai transportasi umum memiliki beberapa keunggulan diantaranya memiliki waktu tempuh yang lebih dapat diprediksi karena terhindar dari kemacetan jalan raya dan juga mampu melayani penumpang yang jauh lebih banyak dalam sekali perjalanan dibandingkan dengan sarana transportasi umum darat lainnya.

Penjadwalan dan perencanaan kapasitas Kereta Api terkait erat dengan tingkat kepuasan penggunanya dan tingkat keuntungan usaha dari penyelenggara jasa layanan Kereta api tersebut. Lai dan Barkan [1] menyatakan bahwa manajemen kapasitas yang efektif merupakan kunci sukses dari penyelenggara jasa layanan Kereta api akan tetapi hal ini tidaklah mudah. Layanan Kereta api yang over-capacity akan membuat pengguna kecewa dan beralih pada moda transportasi lain selain itu juga membuat penyelenggara layanan Kereta api kehilangan potensi pendapatan dari para calon penumpang yang tidak tertampung. Di lain pihak, under-capacity akan membuat penyelenggara layanan Kereta api menanggung beban tambahan akibat gerbong yang tidak terisi. Oleh karena itu, diperlukan sebuah peramalan yang cukup tepat dalam memperkirakan jumlah penumpang Kereta api sehingga dapat dilakukan penyesuaian kapasitas layanan sesuai kebutuhan.

Back-propagation Neural Network (BPNN) merupakan teknik klasifikasi dan peramalan yang paling populer menggunakan supervised learning neural network. Akan tetapi, menurut Chen dan $\mathrm{Su}$ [2], teknik BPNN terbilang lambat konvergensinya dan memiliki tendensi dapat terjebak dalam lokal minima. Di lain pihak, menurut Riedmiller (1993) dalam [2] Resilient Back-propagation (Rprop) merupakan teknik yang memiliki konvergensi cepat dan masih menjaga akurasinya.

Penelitian ini bertujuan untuk melakukan peramalan penumpang Kereta api menggunakan teknik Rprop sehingga dapat dilakukan penyesuaian kapasitas layanan sesuai kebutuhan dengan harapan dapat meningkatkan kepuasan pengguna layanan sekaligus tingkat keuntungan dari penyelenggara jasa layanan Kereta api.

\section{Tinjauan Pustaka}

\subsection{Back-propagation Neural Network}

Jaringan saraf tiruan (Artificial Neural Network) menurut Russel dan Novig (2013) dalam [3] adalah sebuah sistem yang terdiri atas sekelompok unit pemroses yang dimodelkan untuk pemrosesan informasi yang meniru cara kerja sistem saraf biologis seperti jaringan saraf manusia. Pemodelan ini didasari oleh kemampuan otak manusia dalam mengorganisir neuron sehingga mampu mengenali pola secara efektif [4]. Namun, pemodelan ANN jauh lebih sederhana dibanding otak manusia yang sebenarnya. Banyak sistem otak manusia yang harus disimplifikasi agar dapat dimodelkan ke dalam dunia komputer. Arsitektur neural network dapat dilihat pada Gambar 1 [5].

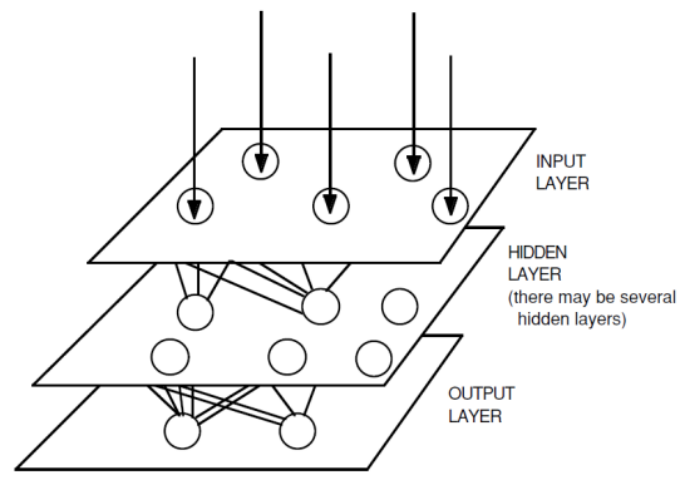

Gambar 1 Arsitektur Neural Network

Back-propagation merupakan salah satu algoritma pembelajaran dalam ANN. Algoritma ini memiliki dua tahap perhitungan, yaitu perhitungan maju yang dilakukan untuk menghitung error antara output ANN dengan target yang diinginkan. Tahap kedua adalah perhitungan mundur 
yang menggunakan error yang telah didapatkan untuk memberbaiki bobot pada semua neuron yang ada.

\subsection{Resilent Back-propagation (Rprop)}

Resilient Back-propagation atau biasa disingkat Rprop dibuat oleh Martin Riedmiller dan Heinrich Braun pada tahun 1992 [6]. Algoritma ini tidak jauh berbeda dengan algortima back-propagation dan merupakan perbaikan dari algortima backpropagation. Menurut McCaffrey [7], ada dua keunggulan algortima Rprop dibandingkan algoritma pendahulunya (back-propagation). Pertama, proses pelatihan yang lebih cepat, dan yang kedua, Rprop tidak mengharuskan untuk menentukan nilai parameter apa pun dalam perhitungannya. Sementara, algoritma Backpropagation memerlukan parameter rasio pembelajaran (learning rate), dan biasanya juga memerlukan parameter momentum. Kerugian algoritma ini yaitu implementasinya yang cukup rumit.

Mathworks (1999) dalam [8] menyatakan, secara sederhana algoritma ini menggunakan tanda turunan untuk menentukan arah perbaikan bobot-bobot. Besarnya perubahan setiap bobot ditentukan oleh suatu faktor yang diatur pada parameter yang disebut delt_inc dan delt_dec. Apabila gradien fungsi error berubah tanda dari satu iterasi ke iterasi berikutnya, maka bobot akan berkurang sebesar delt_dec. Sebaliknya apabila gradien error tidak berubah tanda dari satu iterasi ke iterasi berikutnya, maka bobot akan berkurang sebesar delt_inc. Apabila gradien error sama dengan nol maka perubahan sama dengan perubahan bobot sebelumnya. Pada awal iterasi, besarnya perubahan bobot diinisalisasikan dengan parameter delta0. Besarnya perubahan tidak boleh melebihi batas maksimum yang terdapat pada parameter deltamax, apabila perubahan bobot melebihi batas maksimum perubahan bobot, maka perubahan bobot akan ditentukan sama dengan maksimum perubahan bobot.

Algoritma Rprop membuat dua perubahan signifikan [7], pertama, Rprop tidak menggunakan besarnya gradien untuk menentukan perubahan bobot tapi hanya menggunakan tanda dari gradien. Gradien adalah kumpulan semua turunan parsial untuk semua bobot dan bias dari neural network. Kedua, Rprop mempertahankan perubahan bobot terpisah untuk setiap bobot dan bias, dan menyesuaikan perubahan ini selama pelatihan.

\subsection{Fungsi Aktivasi}

Dalam neural network, bagian yang paling penting adalah fungsi aktivasinya atau seringkali disebut juga dengan threshold function maupun transfer function. Karakteristik fungsi aktivasi BPNN harus bersifat kontinu, differentiable, dan tidak turun secara monoton [9]. Fungsi aktivasi merupakan fungsi matematis yang berguna untuk membatasi dan menentukan jangkauan output suatu neuron [10]. Fungsi aktivasi yang digunakan pada penelitian ini adalah:

1. Sigmoid Biner (Logistik)

Fungsi aktivasi sigmoid biner memiliki nilai output pada range nol sampai satu [0,1] dan didefinisikan sebagai berikut:

$$
f(x)=\frac{1}{1+e^{-x}}
$$

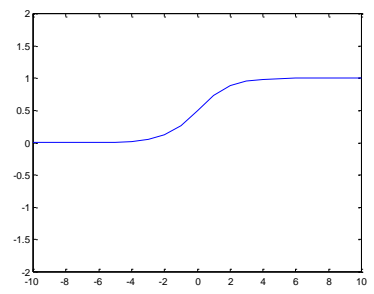

Gambar 2 Fungsi Aktivasi Sigmoid Biner

2. Fungsi Hyperbolic Tangent (tanh)

Output dari fungsi ini memiliki range antara satu sampai minus satu $[-1,1]$ dan didefinisikan sebagai berikut:

$$
f(x)=\frac{e^{x}-e^{-x}}{e^{x}+e^{-x}}
$$

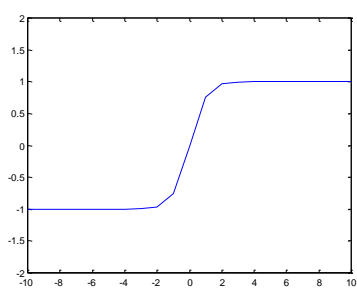

Gambar 3 Fungsi Aktivasi Hyperbolic Tangent 


\subsection{MAPE}

MAPE atau Mean Absolute Percetage Error adalah ukuran akurasi dari suatu prediksi atau suatu peramalan. Dalam penelitian ini MAPE digunakan untuk memilih model Rprop neural network terbaik. Berikut rumusan dari MAPE:

$$
M A P E=\left(\frac{100 \%}{n}\right) \sum_{t=1}^{n}\left|\frac{A t-F t}{A t}\right|
$$

Dimana,

At: Jumlah penumpang KA pada periode ke-t,

Ft: Hasil prediksi/peramalan jumlah penumpang KA pada periode ke-t,

n : Jumlah observasi.

Interpretasi dari nilai MAPE menurut Lewis (1982:40) dalam [11] yaitu:

$<10 \%$ : peramalan sangat akurat,

10\%-20\% : peramalan akurat,

20\%-50\% : peramalan cukup akurat,

$>50 \%$ : peramalan tidak akurat

\section{Metode Peneltian}

\subsection{Sumber Data}

Data yang digunakan adalah data jumlah penumpang kereta api yang dikumpulkan oleh Badan Pusat Statistik dari PT Kereta Api Indonesia dan PT. KAI Commuter Jabodetabek. Periode data dimulai dari Januari 2006 hingga April 2018. Set data yang digunakan merupakan level bulanan sebanyak 148 observasi.

\subsection{Tahapan Penelitian}

Langkah-langkah dalam penelitian ini mencakup:

1. Persiapan data, terdiri dari:

a. Pemeriksaan data untuk melihat apakah terdapat data hilang (missing) atau tidak, dan

b. Pembagian data menjadi data training dan data testing.

2. Pembentukan model peramalan dengan Resilient Back-propagation (Rprop) Neural Network, dengan tahapan:

a. Penentuan parameter, seperti jumlah hidden nodes, fungsi aktivasi/transfer yang akan digunakan, dan sebagainya. b. Proses pelatihan jaringan syaraf tiruan (Neural Network Training) menggunakan data training dan parameter-parameter yang sudah ditetapkan sebelumnya.

c. Pemilihan parameter yang menghasilkan nilai MAPE terkecil.

d. Pembentukan model peramalan dengan nilai parameter terpilih.

3. Peramalan menggunakan model yang dibentuk pada tahap sebelumnya.

4. Uji performa (validasi) hasil peramalan dengan menggunakan nilai MAPE.

\section{Hasil dan Pembahasan}

\subsection{Persiapan Data}

Data yang diperoleh untuk penelitian ini ada sebanyak 148 record untuk masingmasing wilayah kereta api (KA), dimana 136 diantaranya (periode Januari 2006 hingga April 2017) digunakan sebagai data training pada tahap pembentukan model, dan 12 lainnya (periode Mei 2017 hingga April 2018) digunakan sebagai data testing untuk menguji performa dari hasil peramalan. Gambar 4 menunjukkan pola dari jumlah penumpang kereta api periode Januari 2006 hingga April 2018.

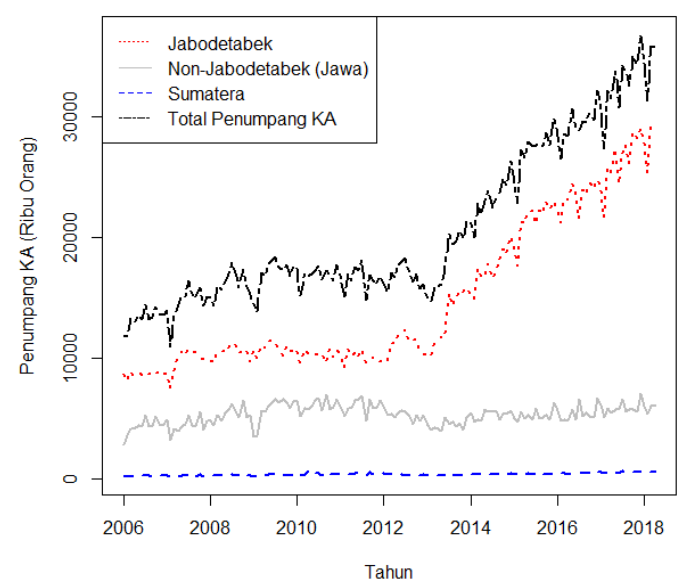

Gambar 4 Plot Time Series Jumlah Penumpang Kereta Api berdasarkan Wilayah Kereta Api

\subsection{Pembentukan Model Peramalan}

Model peramalan yang perlu dibentuk pada tahap ini adalah empat model yang terdiri dari model peramalan untuk Jumlah Penumpang KA Wilayah Jabodetabek, untuk 
Jumlah Penumpang KA Wilayah NonJabodetabek (Jawa), untuk Jumlah Penumpang KA Wilayah Sumatera, dan untuk Jumlah Penumpang KA Keseluruhan (Indonesia). Pembentukan model diawali dengan proses pelatihan jaringan syaraf tiruan (neural network) menggunakan data training. Pada proses ini akan dilakukan pelatihan dengan arsitektur/struktur neural network yang berbeda-beda.

Arsitektur neural network terdiri dari input layer, hidden layer, dan output layer. Beberapa parameter yang digunakan dalam hidden layer diantaranya jumlah hidden nodes dan fungsi aktivasi. Jumlah hidden nodes yang digunakan mulai dari lima hidden nodes hingga 15 hidden nodes, sedangkan fungsi aktivasi yang digunakan yaitu Logistic (Sigmoid Biner) dan Hyperbolic Tangent (tanh). Sementara itu, stepmax/epoch ditetapkan 100000, jumlah pengulangan untuk pelatihan Rprop neural network ditetapkan sebanyak 20 kali dan target error (threshold) ditetapkan 0,01.

Proses pelatihan menggunakan kombinasi dari seluruh parameter tersebut, sehingga menghasilkan 22 kandidat model untuk masing-masing wilayah KA atau total 88 kandidat model. Hasil pelatihan Rprop neural network menggunakan package "nnfor" dan package "neuralnet" pada Program R disajikan pada Tabel 1-4.

Tabel 1.Hasil Pelatihan untuk Data Jumlah Penumpang KA Wilayah Jabodetabek

\begin{tabular}{cccrc}
\hline No. & $\begin{array}{c}\text { Hidden } \\
\text { Nodes }\end{array}$ & $\begin{array}{c}\text { Fungsi } \\
\text { Aktivasi }\end{array}$ & MSE & $\begin{array}{c}\text { MAPE } \\
(\%)\end{array}$ \\
\hline 1 & 5 & logistic & 12348,44 & 0,58 \\
2 & 5 & tanh & 17808,37 & 0,71 \\
$\ldots$ & $\ldots$ & $\ldots$ & $\ldots$ & $\ldots$ \\
19 & 14 & logistic & 576,14 & 0,10 \\
20 & 14 & tanh & 927,66 & 0,12 \\
21 & 15 & logistic & 786,31 & 0,11 \\
22 & 15 & tanh & 938,14 & 0,12 \\
\hline
\end{tabular}

Tabel 2.Hasil Pelatihan untuk Data Jumlah Penumpang KA Wilayah NonJabodetabek (Jawa)

\begin{tabular}{cccrc}
\hline No. & $\begin{array}{c}\text { Hidden } \\
\text { Nodes }\end{array}$ & $\begin{array}{c}\text { Fungsi } \\
\text { Aktivasi }\end{array}$ & MSE & $\begin{array}{c}\text { MAPE } \\
(\%)\end{array}$ \\
\hline 1 & 5 & logistic & 7813,40 & 1,10 \\
2 & 5 & tanh & 7079,56 & 1,02 \\
$\ldots$ & $\ldots$ & $\ldots$ & $\ldots$ & $\ldots$ \\
19 & 14 & logistic & 382,10 & 0,16 \\
20 & 14 & tanh & 363,55 & 0,16 \\
21 & 15 & logistic & 343,44 & 0,16 \\
22 & 15 & tanh & 291.98 & 0.14 \\
\hline
\end{tabular}

Tabel 3. Hasil Pelatihan untuk Data Jumlah Penumpang KA Wilayah Sumatera

\begin{tabular}{cccrc}
\hline No. & $\begin{array}{c}\text { Hidden } \\
\text { Nodes }\end{array}$ & $\begin{array}{c}\text { Fungsi } \\
\text { Aktivasi }\end{array}$ & MSE & $\begin{array}{c}\text { MAPE } \\
(\%)\end{array}$ \\
\hline 1 & 5 & logistic & 273.09 & 2.20 \\
2 & 5 & tanh & 225.25 & 2.28 \\
$\ldots$ & $\ldots$ & $\ldots$ & $\ldots$ & $\ldots$ \\
19 & 14 & logistic & 8.24 & 0.28 \\
20 & 14 & tanh & 20.11 & 0.41 \\
21 & 15 & logistic & 23.12 & 0.39 \\
22 & 15 & tanh & 15.00 & 0.37 \\
\hline
\end{tabular}

Tabel 4. Hasil Pelatihan untuk Data Jumlah Penumpang KA Indonesia

\begin{tabular}{cccrc}
\hline No. & $\begin{array}{c}\text { Hidden } \\
\text { Nodes }\end{array}$ & $\begin{array}{c}\text { Fungsi } \\
\text { Aktivasi }\end{array}$ & MSE & $\begin{array}{c}\text { MAPE } \\
(\%)\end{array}$ \\
\hline 1 & 5 & logistic & 191055.52 & 1.65 \\
2 & 5 & Tanh & 204172.29 & 1.74 \\
$\ldots$ & $\ldots$ & $\ldots$ & $\ldots$ & $\ldots$ \\
17 & 13 & logistic & 67480.44 & 0.68 \\
18 & 13 & Tanh & 101058.01 & 0.91 \\
$\ldots$ & $\ldots$ & $\ldots$ & $\ldots$ & $\ldots$ \\
22 & 15 & Tanh & 86200.03 & 0.80 \\
\hline
\end{tabular}

Pada tabel tersebut terlihat bahwa perubahan jumlah hidden nodes mempengaruhi hasil prediksi, makin banyak jumlah hidden nodes nilai MSE dan MAPE dari hasil prediksi cenderung makin kecil. Baris yang diberi warna abu-abu pada tabel adalah arsitektur Rprop neural network dengan nilai MAPE dan MSE paling kecil (minimum) untuk masing-masing data jumlah penumpang KA. Berikut keempat arsitektur Rprop neural network dimaksud: 
1. Untuk data jumlah penumpang KA wilayah Jabodetabek, nilai MAPE dan MSE minimum ditemukan pada arsitektur neural network 17-14-1 dengan fungsi transfer yang digunakan adalah Logistic. Input neuron yang digunakan pada arsitektur tersebut adalah 11 variabel seasonal dummy dan data pada lag 1, lag 2, lag 5, lag 7, lag 10, dan lag 12. Pada Gambar 5-8, variabel seasonal dummy ditandai dengan warna pink.

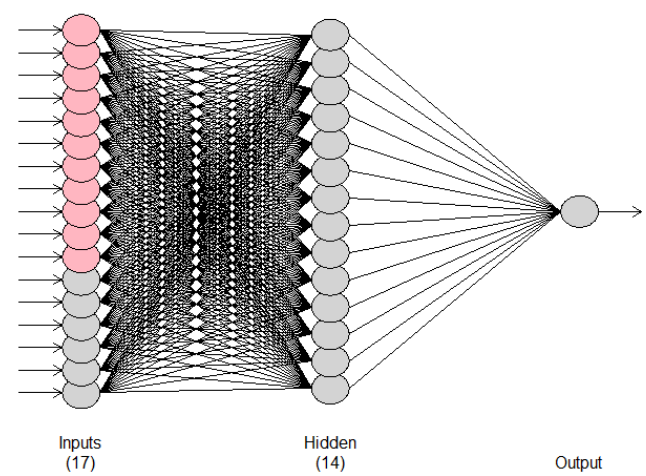

Gambar 5 Plot Multi Layer Perceptron (MLP) untuk Data Penumpang KA Wilayah Jabodetabek

2. Untuk data jumlah penumpang KA wilayah Non-Jabodetabek (Jawa), nilai MAPE dan MSE minimum ditemukan pada arsitektur neural network 16-15-1 dengan fungsi transfer yang digunakan adalah Hyperbolic Tangent. Input neuron yang digunakan pada arsitektur tersebut adalah 11 variabel seasonal dummy dan data pada lag 1 , lag 2 , lag 3 , lag 4 , dan lag 11.

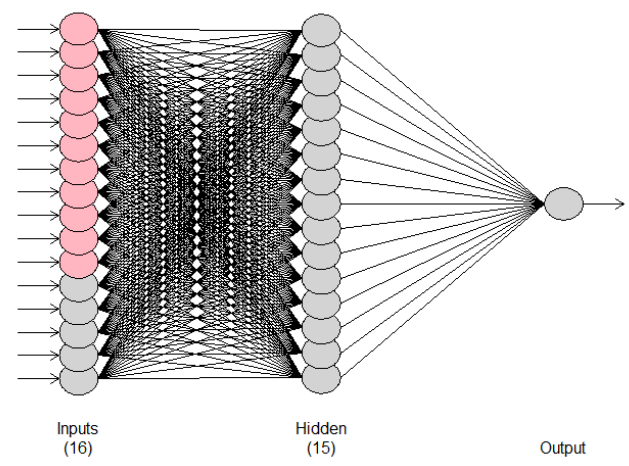

Gambar 6 Plot Multi Layer Perceptron (MLP) untuk Data Penumpang KA Wilayah Non-Jabodetabek (Jawa)
3. Untuk data jumlah penumpang KA wilayah Sumatera, nilai MAPE dan MSE minimum ditemukan pada arsitektur neural network 16-14-1 dengan fungsi transfer yang digunakan adalah Logistic. Input neuron yang digunakan pada arsitektur tersebut adalah 11 variabel seasonal dummy dan data pada lag 1 , lag 2, lag 3, lag 4, dan lag 12.

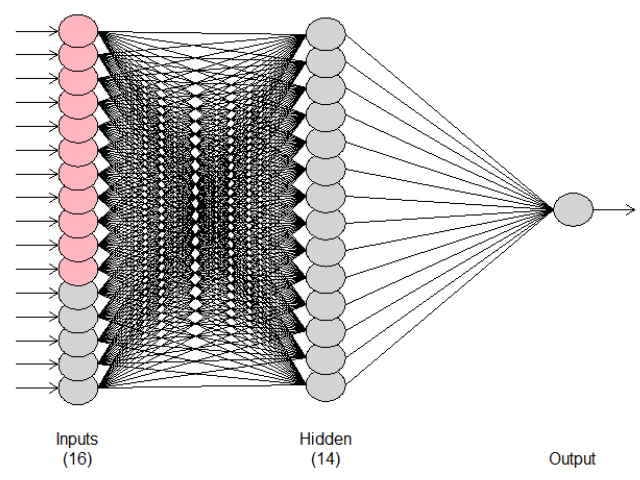

Gambar 7 Plot Multi Layer Perceptron

(MLP) untuk Data Penumpang KA Wilayah Jabodetabek

4. Untuk data jumlah Penumpang KA keseluruhan (Indonesia), nilai MAPE dan MSE minimum ditemukan pada arsitektur neural network 13-13-1 dengan fungsi transfer yang digunakan adalah Logistic. Input neuron yang digunakan pada arsitektur tersebut adalah 11 variabel seasonal dummy dan data pada lag 1 dan lag 2.

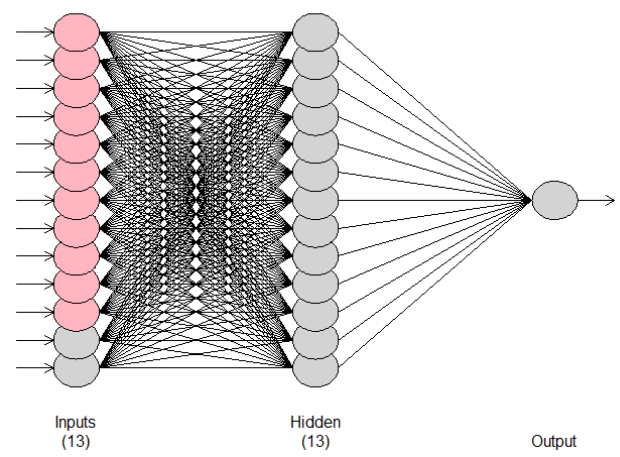

Gambar 8 Plot Multi Layer Perceptron (MLP) untuk Data Penumpang KA Indonesia 


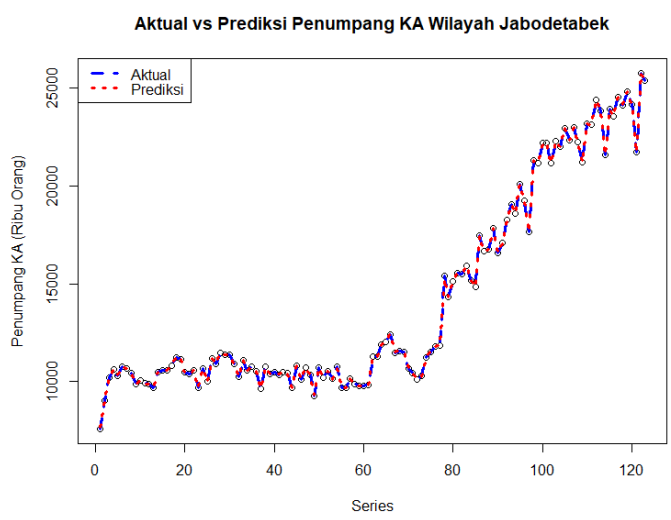

Aktual vs Prediksi Penumpang KA Wilayah Non-Jabodetabek (Jawa)
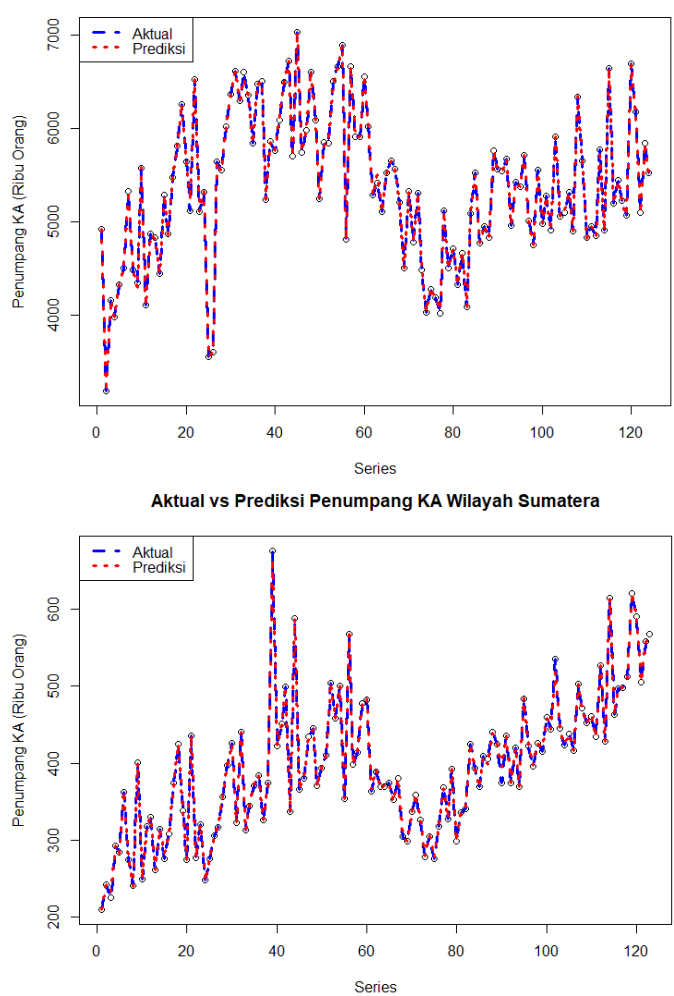

Aktual vs Prediksi Penumpang KA

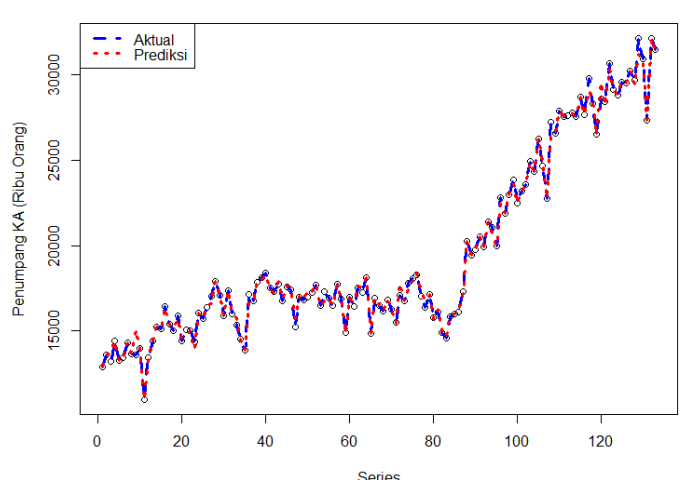

Gambar 9 Plot Data Aktual dan Prediksi Jumlah Penumpang Kereta Api Periode Januari 2006 - April 2017
Nilai MAPE dibawah $10 \%$ menunjukkan kemampuan prediksi yang sangat baik (sangat akurat), hal tersebut dapat terlihat pada Gambar 9. Nilai prediksi (garis merah) hampir berimpitan sempurna dengan nilai aktual (garis biru).

\subsection{Peramalan (Forecasting)}

Dengan menggunakan arsitektur Rprop neural network terbaik hasil tahap pembentukan model, dilakukan peramalan untuk 12 bulan kedepan dari periode terakhir data training. Peramalan dilakukan untuk Wilayah KA Jabodetabek, Wilayah KA Non-Jabodetabek (Jawa), Wilayah KA Sumatera, dan untuk total keseluruhan wilayah KA. Nilai aktual dan ramalan jumlah penumpang KA secara visual dapat dilihat pada Gambar 10-13.

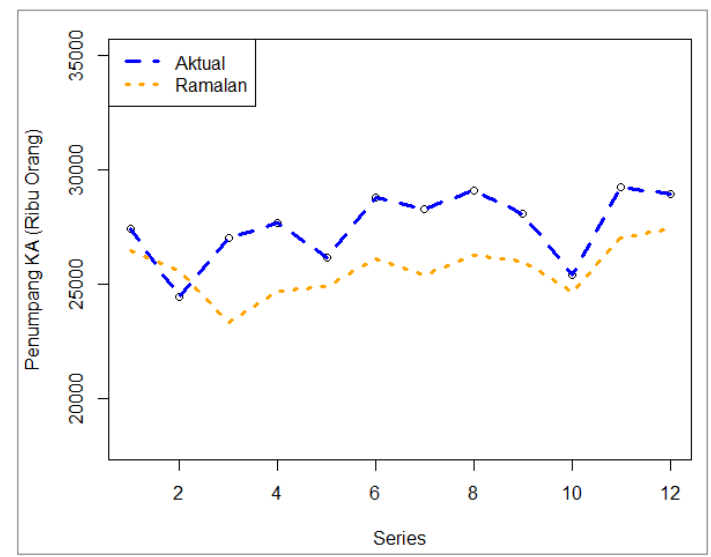

Gambar 10 Plot Data Aktual dan Ramalan Penumpang KA Wilayah Jabodetabek

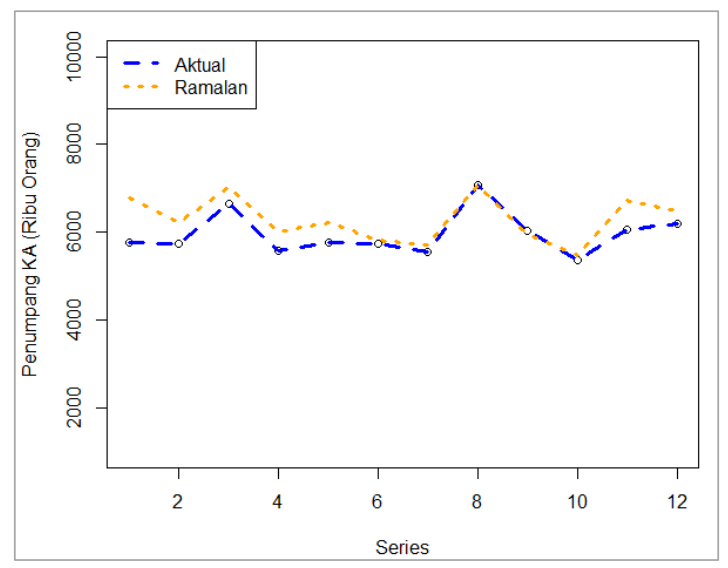

Gambar 11 Plot Data Aktual dan Ramalan Penumpang KA Wilayah Non-Jabodetabek (Jawa) 


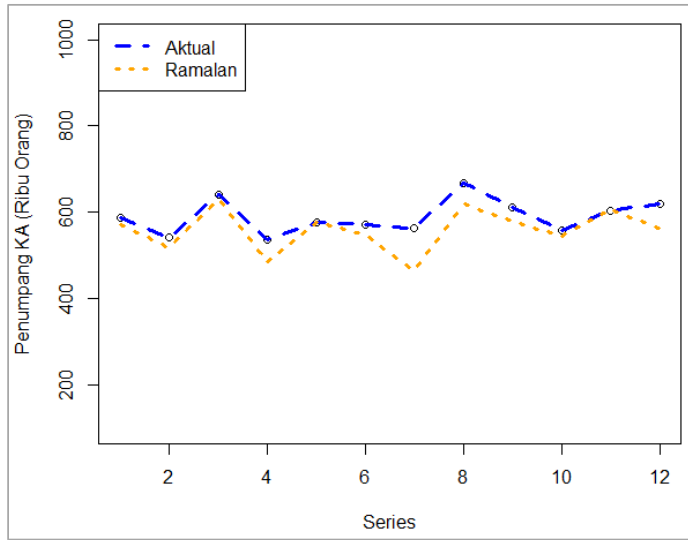

Gambar 12 Plot Data Aktual dan Ramalan Penumpang KA Wilayah Sumatera

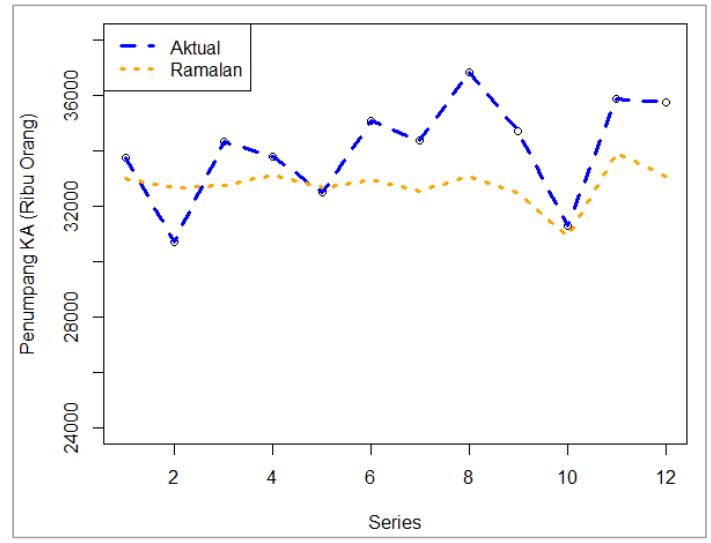

Gambar 13 Plot Data Aktual dan Ramalan Penumpang KA Indonesia

Uji performa hasil peramalan pada penelitian ini merupakan tahapan menghitung akurasi dari hasil peramalan menggunakan mean absolute percentage error (MAPE). Semakin kecil nilai MAPE, maka akurasi suatu peramalan semakin tinggi atau semakin akurat. Suatu peramalan dikatakan sangat akurat apabila memiliki nilai MAPE dibawah $10 \%$. Nilai MAPE hasil peramalan Wilayah KA Jabodetabek, Wilayah KA Non-Jabodetabek (Jawa), Wilayah KA Sumatera, dan nilai MAPE hasil peramalan total keseluruhan wilayah (Indonesia) berturut-turut adalah $7.50 \%$, $5.89 \%, 5.36 \%$, dan $4.80 \%$. Hal tersebut menunjukkan empat arsitektur neural network yang digunakan untuk masingmasing wilayah kereta api (KA) menghasilkan peramalan yang sangat akurat. Hasil peramalan jumlah penumpang KA untuk masing-masing wilayah KA periode
Mei 2017 sampai April 2018 dapat dilihat pada Lampiran.

\section{Kesimpulan}

Berdasarkan analisis yang dilakukan pada data jumlah penumpang kereta api, dapat disimpulkan bahwa:

1. Performa model neural network dengan Resilient Back-propagation (Rprop) yang dibentuk dari data training dan divalidasi dengan data testing memberikan tingkat akurasi prediksi serta tingkat akurasi peramalan yang sangat baik dengan nilai mean absolute percentage error (MAPE) kurang dari $10 \%$ untuk masing-masing model.

2. Nilai MAPE untuk masing-masing peramalan jumlah penumpang KA adalah: untuk wilayah Jabodetabek memberikan nilai MAPE sebesar $7.50 \%$, untuk non Jabodetabek (Jawa) memberikan nilai MAPE sebesar 5.89\%. Sedangkan untuk wilayah Sumatra memberikan nilai MAPE sebesar 5.36\%. Sementara itu, hasil peramalan total keseluruhan wilayah (Indonesia) memberikan nilai MAPE sebesar $4.80 \%$. Artinya, empat arsitektur neural network dengan Rprop dapat digunakan untuk kasus ini dengan hasil peramalan yang sangat akurat.

\section{Referensi}

[1] Y.-C. (Rex) Lai dan C. P. L. Barkan, "Enhanced Parametric Railway Capacity Evaluation Tool," Transportation Research Record: Journal of the Transportation Research Board, vol. 2117, no. 1, hlm. 33-40, Jan 2009.

[2] C.-S. Chen dan S.-L. Su, "Resilient Backpropagation Neural Network for Approximation 2-D GDOP," dipresentasikan pada IMECS 2010, Hong Kong, 2010, vol. 2.

[3] E. R. Zulvima, "Visualisasi dari Klasterisasi dan Peramalan Kualitas Udara Kota Surabaya Menggunakan Metode Klasterisasi K-Means dan 
Peramalan Artificial Neural Network," Skripsi, Institut Teknologi Sepuluh Nopember, Surabaya, 2017.

[4] Suyanto, Data Mining untuk Klasifikasi dan Klasterisasi Data. INFORMATIKA, 2017.

[5] D. Anderson dan G. McNeill, "Artificial Neural Networks Technology," Kaman Sciences Corporation, New York, A DACS State-of-the-Art Report, Agu 1992.

[6] wikipedia, "Rprop," Wikipedia, 2016. [Daring]. Tersedia pada: https://en.wikipedia.org/wiki/Rprop.

[7] J. McCaffrey, "How to Use Resilient Back Propagation to Train Neural Networks," Visual Studio Magazine, 09Mar-2015. [Daring]. Tersedia pada: https://visualstudiomagazine.com/Articles /2015/03/01/Resilient-Back-

Propagation.aspx?

[8] N. Susanto, "Pengembangan Model Jaringan Syaraf Tiruan Resilient Backpropagation untuk Identifikasi Pembicara dengan Praproses MFCC," Skripsi, Institut Pertanian Bogor, Bogor, 2007.

[9] L. Fausett, Fundamentals of Neural Network: Architectures, Algorithms, and Application. New Jersey: Prentice Hall, 1994.

[10] S. S. Haykin, Neural Networks: A Comprehensive Foundation, 2 ed. New Jersey: Prentice Hall, 1999.

[11] J. J. M. Moreno, A. P. Pol, A. S. Abad, dan B. C. Blasco, "Using the R-MAPE index as a resistant measure of forecast accuracy," Psicothema, vol. 25, no. 4, hlm. 500-506, Nov 2013.

[12] Amrin, "Peramalan Tingkat Inflasi Indonesia Menggunakan Neural Network Backpropagation Berbasis Metode Time
Series," Jurnal Techno Nusa Mandiri, vol. 11, no. 2, hlm. 129-136, 2014.

[13] M. Fajar, "Peramalan Produksi Cabai Rawit dengan Neural Network," 2017.

[14] S. Fritsch, F. Guenther, M. Suling, dan S. M. Mueller, Package 'neuralnet.' 2016.

[15] G. A. Saputro dan M. Asri, Anggaran Perusahaan, 3 ed. Yogyakarta: BPFE, 2000.

[16] J. Heizer dan B. Render, Manajemen Operasi Buku 1, 9 ed. Jakarta: Salemba Empat, 2009.

[17] B. Karlik dan A. V. Olgac, "Performance Analysis of Various Activation Functions in Generalized MLP Architectures of Neural Networks," International Journal of Artificial Intelligence And Expert Systems (IJAE), vol. 1, no. 4, hlm. 111$122,2011$.

[18] N. Kourentzes, Package 'nnfor.' 2017.

[19] W. S. McCulloch dan W. Pitts, "A logical calculus of the ideas immanent in nervous activity," Bulletin of Mathematical Biophysics, vol. 5, no. 4, hlm. 115-133, Des 1943.

[20] M. A. Razak dan E. Riksakomara, "Peramalan Jumlah Produksi Ikan dengan Menggunakan Backpropagation Neural Network (Studi Kasus: UPTD Pelabuhan Perikanan Banjarmasin)," JURNAL TEKNIK ITS, vol. 6, no. 1, hlm. 142148, 2017.

[21] W. Saputra, Tulus, M. Zarlis, R. W. Sembiring, dan D. Hartama, "Analysis Resilient Algorithm on Artificial Neural Network Backpropagation," dalam Journal of Physics: Conference Series, 2017, vol. 930, hlm. 012035. 
Oktober 2018. Vol. 04 No. 02

ISSN: 2527-3159

E-ISSN: 2527-3167

\section{Lampiran}

Tabel 5 Hasil Peramalan Jumlah Penumpang Kereta Api (Ribu Orang)

\begin{tabular}{|c|c|c|c|c|c|}
\hline Wilayah & Bulan & Nilai Aktual & $\begin{array}{c}\text { Nilai } \\
\text { Ramalan }\end{array}$ & Residual & MAPE (\%) \\
\hline \multirow[t]{12}{*}{ Jabodetabek } & Mei 2017 & 27385.00 & 26425.18 & 959.82 & \multirow{12}{*}{7.50} \\
\hline & Juni 2017 & 24432.00 & 25583.31 & -1151.31 & \\
\hline & Juli 2017 & 27016.00 & 23296.11 & 3719.89 & \\
\hline & Agustus 2017 & 27679.00 & 24692.44 & 2986.56 & \\
\hline & Sept. 2017 & 26158.00 & 24875.94 & 1282.06 & \\
\hline & Oktober 2017 & 28765.00 & 26098.91 & 2666.09 & \\
\hline & November 2017 & 28246.00 & 25379.16 & 2866.84 & \\
\hline & Desember 2017 & 29059.00 & 26235.71 & 2823.29 & \\
\hline & Januari 2018 & 28075.00 & 26012.92 & 2062.08 & \\
\hline & Februari 2018 & 25362.00 & 24619.66 & 742.34 & \\
\hline & Maret 2018 & 29223.00 & 27014.23 & 2208.77 & \\
\hline & Apri 2018 & 28943.00 & 27401.47 & 1541.53 & \\
\hline Non- & Mei 2017 & 5772.00 & 6768.36 & -996.36 & \multirow{12}{*}{5.89} \\
\hline Jabodetabek & Juni 2017 & 5749.00 & 6219.55 & -470.55 & \\
\hline (Jawa) & Juli 2017 & 6653.00 & 7016.80 & -363.80 & \\
\hline & Agustus 2017 & 5576.00 & 5992.58 & -416.58 & \\
\hline & Sept. 2017 & 5763.00 & 6224.38 & -461.38 & \\
\hline & Oktober 2017 & 5733.00 & 5817.42 & -84.42 & \\
\hline & November 2017 & 5552.00 & 5706.04 & -154.04 & \\
\hline & Desember 2017 & 7081.00 & 7085.75 & -4.75 & \\
\hline & Januari 2018 & 6032.00 & 5943.28 & 88.72 & \\
\hline & Februari 2018 & 5359.00 & 5471.85 & -112.85 & \\
\hline & Maret 2018 & 6049.00 & 6740.41 & -691.41 & \\
\hline & Apri 2018 & 6193.00 & 6498.28 & -305.28 & \\
\hline \multirow[t]{12}{*}{ Sumatera } & Mei 2017 & 588.00 & 569.85 & 18.15 & \multirow{12}{*}{5.36} \\
\hline & Juni 2017 & 542.00 & 517.83 & 24.17 & \\
\hline & Juli 2017 & 641.00 & 630.36 & 10.64 & \\
\hline & Agustus 2017 & 536.00 & 486.68 & 49.32 & \\
\hline & Sept. 2017 & 577.00 & 577.36 & -0.36 & \\
\hline & Oktober 2017 & 572.00 & 547.20 & 24.80 & \\
\hline & November 2017 & 563.00 & 463.49 & 99.51 & \\
\hline & Desember 2017 & 667.00 & 619.33 & 47.67 & \\
\hline & Januari 2018 & 610.00 & 580.12 & 29.88 & \\
\hline & Februari 2018 & 557.00 & 543.35 & 13.65 & \\
\hline & Maret 2018 & 603.00 & 605.99 & -2.99 & \\
\hline & Apri 2018 & 619.00 & 563.87 & 55.13 & \\
\hline \multirow[t]{12}{*}{ Total } & Mei 2017 & 33745.00 & 32990.29 & 754.71 & \multirow{12}{*}{4.80} \\
\hline & Juni 2017 & 30723.00 & 32644.87 & -1921.87 & \\
\hline & Juli 2017 & 34310.00 & 32745.96 & 1564.04 & \\
\hline & Agustus 2017 & 33791.00 & 33101.98 & 689.02 & \\
\hline & Sept. 2017 & 32498.00 & 32662.95 & -164.95 & \\
\hline & Oktober 2017 & 35070.00 & 32964.11 & 2105.89 & \\
\hline & November 2017 & 34361.00 & 32526.74 & 1834.26 & \\
\hline & Desember 2017 & 36807.00 & 33071.01 & 3735.99 & \\
\hline & Januari 2018 & 34717.00 & 32474.73 & 2242.27 & \\
\hline & Februari 2018 & 31278.00 & 30932.04 & 345.96 & \\
\hline & Maret 2018 & 35875.00 & 33910.57 & 1964.43 & \\
\hline & Apri 2018 & 35755.00 & 33082.79 & 2672.21 & \\
\hline
\end{tabular}

